\title{
Kualitas Fisik Daging Kambing Kacang Jantan Muda yang Diberi Rumput Lapang dan Tiga Level Konsentrat
}

\author{
Marselinus Hambakodu ${ }^{1}$, Luh Sri Enawati ${ }^{2}$ \\ ${ }^{1}$ Program Studi Peternakan, Universitas Kristen Wira Wacana Sumba, NTT \\ Jl. R. Suprapto N0. 35 Waingapu \\ ${ }^{2}$ Fakultas Peternakan, Universitas Nusa Cendana, Kupang, NTT \\ Jl.Adisucipto, Penfui, Kupang 8500 \\ Korespondensi Email: mhambakodu91@gmail.com
}

(Diterima: 14-12-2018; disetujui 2-1-2019)

\begin{abstract}
ABSTRAK
Penelitian ini bertujuan untuk mengetahui pengaruh pemberian level konsentrat sebagai pakan suplemen terhadap kualitas fisik daging kambing yang meliputi susut masak, daya ikat air, keempukan dan $\mathrm{pH}$. Penelitian ini menggunakan daging bagian otot Longisimus dorsi dan Bisef femoris dari 12 ekor kambing Kacang jantan muda berumur 6-8 bulan dengan berat badan awal 11,82 $\pm 1,29 \mathrm{~kg}$ (koefisien variasi $10,92 \%$ ). Metode penelitian yang digunakan adalah rancangan acak lengkap 3 perlakuan dan 4 ulangan yaitu $\mathrm{R} 1=$ rumput lapangan ad libitum + konsentrat $0,5 \% \mathrm{BB}, \mathrm{R} 2=$ rumput lapangan ad libitum + konsentrat 0,75\% BB , R3 = rumput lapangan ad libitum + konsentrat 1\% BB. Hasil analisis statistik menunjukkan bahwa perlakuan berpengaruh tidak nyata $(\mathrm{p}>0,05)$ terhadap susut masak, daya ikat air, keempukan dan $\mathrm{pH}$. Pemberian konsentrat sebagai suplemen dengan level 0,5\%; $0,75 \%$ dan $1 \%$ menghasilkan kualitas fisik daging (susut masak, daya ikat air, keempukan dan $\mathrm{pH}$ ) yang relatif sama pada otot Longissimus dorsi dan Biceps femoris dari kambing Kacang jantan muda.
\end{abstract}

Kata kunci: Kambing kacang jantan, konsentrat, sifat fisik daging.

\begin{abstract}
This study aims to determine the effect of level concentrate as a feed supplement on the physical quality of meat of Kacang male goat including cooking loss, water holding capacity, tenderness and $\mathrm{pH}$. This research used meats the muscle section of Longissimus dorsi and Bicep femoris from 12 heads of young male Kacang goat aged 6-8 months with the initial body weight 11,89 $\pm 1,29$ $\mathrm{kg}$ (variation coefficient 10,92\%). The research method used completely randomized design with three treatments and four replicates, i.e.: $\mathrm{R} 1=$ native grass ad libitum + concentrates $0,5 \% \mathrm{BW}, \mathrm{R} 2=$ native grass ad libitum + concentrates $0,75 \% \mathrm{BW}, \mathrm{R} 3=$ native grass ad libitum + concentrates $1 \% \mathrm{BW}$. Statistical analysis showed that the treatment effect insignificant ( $p>0.05)$ against cooking loss, water holding capacity, tenderness and $\mathrm{pH}$. Giving of concentrate as a supplement to the level of $0,5 \% ; 0,75 \%$ and $1 \%$ resulted in the physical quality of the meat (cooking loss, water holding capacity, tenderness and $\mathrm{pH}$ ) were relatively similar to the muscle Longissimus dorsi and Biceps femoris of young male Kacang goats.
\end{abstract}

Keywords: Male Kacang goat, concentrate, the physical quality of meat.

\section{Latar Belakang}

\section{PENDAHULUAN}

Kambing merupakan salah satu ternak penghasil daging yang potensial dan cukup digemari oleh masyarakat Indonesia secara umum serta masyarakat Nusa Tenggara Timur pada khususnya. Pertumbuhan dan produksi ternak kambing Kacang sebagian besar tergantung pada faktor pakan. Mutu dan jumlah pakan yang cukup akan menghasilkan pertumbuhan dan produksi ternak tinggi. Sistem pemeliharaan ternak kambing yang selama ini 
dijalankan petani peternak sangat bergantung pada ketersediaan rumput lapangan yang ada di sekitar lingkungan petani peternak. Rumput lapangan sebagai pakan ternak ruminansia selain mudah diperoleh juga memiliki kemampuan adaptasi yang tinggi terutama di daerah tropis. Sistem pemeliharaan kambing dan bobot potong yang sama menyebabkan profil karkas kambing Kacang jantan sama dan mempengaruhi kualitas nutrisi daging (Mirdhayati et al., 2014).

Pakan suplemen merupakan campuran bahan pakan yang memiliki fungsi spesifik untuk memenuhi kebutuhan nutrisi ternak kambing. Bila komponen tersebut diberikan kepada ternak ruminansia secara bersamaan dalam pakan dapat mengoptimalkan peranan mikroba rumen dalam penggunaan pakan bagi ternak (Onwuka, 1999). Komponen bahan pakan suplemen tersebut adalah berupa dedak padi dan jagung giling sebagai sumber energi, urea sebagai sumber non protein nitrogen bagi mikroba rumen, mineral mix sebagai sumber mineral untuk ternak.

Efisiensi produksi pada usaha penggemukan ternak kambing tercermin dari produksi karkas yang memiliki nilai kualitas daging yang baik dan bernilai ekonomis. Bobot hidup yang semakin meningkat menghasilkan karkas yang meningkat pula, sehingga diharapkan bagian karkas yang berupa daging menjadi lebih besar (Soeparno, 2011). Laju pertumbuhan, nutrisi, umur dan bobot badan adalah faktor-faktor yang mempunyai hubungan erat antara satu dengan lainnya serta dapat mempengaruhi kualitas daging. Nutrisi pakan merupakan salah satu substansi yang mempengaruhi komposisi karkas dan kualitas fisik daging. Respon ternak terhadap manipulasi nutrisi yang diberikan ikut menentukan hasil akhir komposisi karkas serta kualitas daging termasuk kualitas fisik (Soeparno, 2011).

Pemberian pakan suplemen yang baik memberikan keseimbangan antara konsumsi pakan untuk mencukupi kebutuhan nutrisi ternak sehingga produksi daging akan berjalan dengan baik. Naik turunnya konsumsi pakan dapat berhubungan dengan kualitas pakan dan dapat mempengaruhi karakteristik daging yang dihasilkan (Soeparno, 2011). Tujuan penelitian ini untuk mengetahui pengaruh pemberian level konsentrat sebagai suplemen terhadap kualitas fisik daging kambing yang meliputi susut masak, daya ikat air, keempukan dan $\mathrm{pH}$.

\section{MATERI DAN METODE}

\section{Bahan dan alat}

Penelitian ini menggunakan bahan daging yang diambil dari otot Logisimus dorsi dan Bisef femoris kambing Kacang jantan dengan kisaran umur 6-8 bulan dan berat badan awal 11,82 $\mathrm{kg} \pm$ 1,29 (CV 10,92\%). Bahan pakan yang digunakan adalah rumput lapangan sebagai pakan basal dan konsentrat berupa pellet (BR1) 20\%, dedak padi $30 \%$, jagung giling $35 \%$, urea $1 \%$, mineral mix $10 \%$, dan garam $4 \%$. Kandungan nutrient pakan perlakuan seperti tertera pada Tabel 1 .

Tabel 1. Kandungan nutrisi rumput lapangan dan konsentrat

\begin{tabular}{lcc}
\hline Kandungan Nutrisi & Rumput & Konsentrat \\
\hline Bahan Kering (\%) & 27,17 & 91,275 \\
Bahan Organik (\%BK) & 91,44 & 88,745 \\
Protein Kasar (\%BK) & 7,505 & 13,39 \\
Lemak Kasar (\%BK) & 3,77 & 6,185 \\
Serat Kasar (\%BK) & 27,255 & 6,13 \\
Total CHO (\%BK) & 80,16 & 69,17 \\
Bahan Ekstrak Tanpa Nitorgen (\%BK) & 52,915 & 63,18 \\
Gross Energy (MJ/kg) & 16,79 & 17,325 \\
Gross Energy (Kkal/Kg) & 4041,19 & 4124,33 \\
\hline
\end{tabular}

Bahan lain yang digunakan yaitu kertas saring, dan tissue. Alat yang digunakan adalah timbangan merk Yamato berkapasitas 5 kg dengan tingkat kepekaan 10 gram, timbangan elektrik merek Metter PJ 300 berkapasitas $3 \mathrm{~kg}$ dengan kepekaan 0,1 gr, warner-bratzler shear force, penangas air, alat pemberat, termometer bimetal, oven dan $\mathrm{pH}$ meter elektrik, pisau, dan parang. 
Rancangan penelitian adalah metode percobaan (eksperimen) rancangan acak lengkap dengan 3 perlakuan dan 4 ulangan sebagai berikut:

$\mathrm{R} 1=$ Rumput lapangan adlibitum tertimbang + konsentrat $0,5 \% \mathrm{BB}$

$\mathrm{R} 2=$ Rumput lapanganadlibitum tertimbang + konsentrat $0,75 \% \mathrm{BB}$

R3 = Rumput lapangan adlibitum tertimbang + konsentrat $1 \% \mathrm{BB}$

\section{Prosedur pengujian}

\section{Susut Masak}

Pengujian susut masak berdasarkan Soeparno (2011), dilakukan pada sampel daging yang mengalami pemanasan pada suhu $80^{\circ} \mathrm{C}$ selama 60 menit, kemudian didinginkan pada temperature kamar dan selanjutnya didinginkan pada temperature rendah $\pm 0^{\circ} \mathrm{C}$. Sampel daging di lap menggunakan tissue untuk menyerap air pada permukaan daging, kemudian sampel ditimbang.

\section{Daya Ikat Air}

Pengujian daya ikat air menggunakan metode Hamm (1972) dikutip Soeparno, (2011). Sampel daging seberat $0,3 \mathrm{~g}$ diletakkan diatas kertas saring yang telah diketahui beratnya, sampel alam kertas saring diletakkan diantara dua plat kaca setebal $5 \mathrm{~mm}$, kemudian sampel daging dipres dengan beban $35 \mathrm{~kg}$ selama 5 menit. Areal yang tertutup daging telah menjadi pipih, digambar atau ditandai dan diukur luasnya dengan kertas milimeter blok . Luas area basah seluruhnya ditandai dan diukur luasnya dengan kertas milimeter blok. Luas area basah sama dengan daerah basah total dikurangi daerah basah yang tertutup sampel daging, kemudian dihitung.

\section{Keempukan}

Pengujian keempukan daging menggunakan metode metode Warner-Bratzler (Soeparno, 2011) dengan cara shear press. Sampel daging sebanyak 300 gram, direbus hingga temperatur internal daging mencapai $81^{\circ} \mathrm{C}$. Pengukuran temperatur internal daging dilakukan dengan menggunakan termometer bimetal. Setelah bagian internal daging mencapai suhu $81^{\circ} \mathrm{C}$, daging diangkat dan dianginkan \pm 60 menit. Sampel daging diiris searah serabut daging sehingga membentuk empat persegi dengan ukuran luas penampang sampel adalah lebar $1,5 \mathrm{x}$ tebal $0,67 \mathrm{~cm}=1 \mathrm{~cm}^{2}$. Besarnya tekanan yang dibutuhkan untuk memotong daging (sampel) diukur dengan $\mathrm{kg} / \mathrm{cm}^{2}$. Sampel daging hasil pemotongan, diletakkan pada alat pemotongan warner bratzler shear force untuk dilakukan pengukuran. Daging yang telah dicetak diukur keempukannya dengan melihat tekanan gaya pada skala Warner-Bratzler shear yang dinyatakan dalam $\mathrm{kg} / \mathrm{cm}^{2}$.

\section{Derajat Keasaman atau pH}

Pengujian $\mathrm{pH}$ daging menggunakan metode Soeparno (2011). pH daging diukur setelah pemotongan 24 jam untuk mengetahui $\mathrm{pH}$ ultimate dari daging atau karkas. Pengukuran $\mathrm{pH}$ menggunakan $\mathrm{pH}$ meter yang ditusukkan pada sampel daging. Alat $\mathrm{pH}$ meter daging dikalibrasi dengan buffer $\mathrm{pH}$ 7. Ujung $\mathrm{pH}$ meter ditusukkan pada sampel daging dan baca serta catat nilai $\mathrm{pH}$ yang tertera pada layar display alat $\mathrm{pH}$ meter daging. Pengukuran dilakukan beberapa kali untuk memperoleh nilai hasil $\mathrm{pH}$ yang akurat.

\section{Analisis Data}

Data susut masak, daya ikat air, $\mathrm{pH}$, dan keempukan yang diperoleh dianalisis berdasarkan sidik ragam (analysis of variance). Apabila terdapat pengaruh perlakuan maka akan dilakukan uji lanjut Duncan sesuai petunjuk Steel and Torrie (1993).

\section{HASIL DAN PEMBAHASAN}

\section{Susut Masak}

Susut masak daging menunjukkan tidak berbeda nyata $(\mathrm{P}>0,05)$ terhadap perlakuan level pakan konsentrat. Nilai susut masak daging otot L. dorsi (18,94\%-26,67\%), sedangkan ototl $B$. femoris $(18,54 \%-23,35 \%)$. Susut masak daging pada perlakuan pakan R3 dengan level konsentrat $1 \%$ BB mengalami kenaikan dibanding perlakuan pakan konsentrat lainnya. Peningkatan susut masak daging pada perlakuan R3 disebabkan oleh degradasi protein pakan pada R3 tinggi. Hal ini didukung dengan tingkat konsumsi protein kambing Kacang pada R3 lebih tinggi 48,91 g/e/h. Faktor lain yang mempengaruhi susut masak tinggi yaitu daya ikat air tinggi pada perlakuan pakan R3. Nilai susut masak juga memiliki hubungan dengan erat dengan daya mengikat air. Semakin tinggi proses mengikat air maka proses pemanasan air dan cairan nutrisi akan sedikit yang keluar atau terbuang sehingga massa daging yang berkurang sedikit (Isyiqzamiyah et al., 2017). Walaupun konsumsi protein berbeda nyata, tapi tidak memberikan efek yang nyata terhadap susut masak daging. Protein dalam daging relatif stabil meskipun jumlah protein yang dikonsumsi 
berbeda. Daging dengan kandungan protein yang stabil maka akan menghasilkan susut masak yang sama, sejalan dengan daya ikat air yang relatif sama.

Tabel 3. Rata-rata sifat fisik daging kambing Kacang jantan muda pada otot Longissimus dorsi (LD) dan Biceps femoris $(\mathrm{BF})$

\begin{tabular}{llcccc}
\hline & Jenis & \multicolumn{3}{c}{ Perlakuan } & \\
\cline { 3 - 5 } \multicolumn{1}{c}{ Parameter } & Otot & $\mathrm{R}_{1}$ & $\mathrm{R}_{2}$ & $\mathrm{R}_{3}$ & Rataan \\
\hline Susut masak (\%) & $\mathrm{LD}$ & $18,94 \pm 10,31$ & $19,31 \pm 10,21$ & $26,67 \pm 19,67$ & $21,64 \pm 13,30$ \\
Keempukan $\left(\mathrm{kg} / \mathrm{cm}^{2}\right)$ & & $0,92 \pm 0,42$ & $0,62 \pm 0,25$ & $0,79 \pm 0,10$ & $0,78 \pm 0,29$ \\
$\mathrm{pH}$ & & $5,52 \pm 0,23$ & $5,66 \pm 0,29$ & $5,27 \pm 0,33$ & $5,48 \pm 0,31$ \\
Daya ikat air (\%) & & $39,05 \pm 4,27$ & $35,28 \pm 4,17$ & $35,57 \pm 2,31$ & $36,63 \pm 3,79$ \\
Susut masak (\%) & $\mathrm{BF}$ & $18,54 \pm 10,94$ & $19,92 \pm 8,93$ & $23,35 \pm 11,47$ & $20,61 \pm 9,73$ \\
Keempukan $\left(\mathrm{kg} / \mathrm{cm}^{2}\right)$ & & $0,58 \pm 0,24$ & $0,55 \pm 0,18$ & $0,53 \pm 0,23$ & $0,55 \pm 0,20$ \\
pH & & $5,56 \pm 0,12$ & $5,85 \pm 0,39$ & $5,58 \pm 0,18$ & $5,66 \pm 0,27$ \\
Daya ikat air (\%) & & $33,94 \pm 2,12$ & $34,95 \pm 4,30$ & $36,62 \pm 3,46$ & $35,17 \pm 3,30$ \\
\hline
\end{tabular}

Keterangan: Angka-angka merupakan nilai tengah dari 3 pengukuran $\pm \mathrm{SD}$

Nilai susut masak pada penelitian ini lebih rendah dari hasil penelitian Kamlasi (2006), yang memberikan level konsentrat $25 \%, 30 \%$, $35 \%$ dan $40 \%$ pada ternak kambing lokal jantan dengan kisaran susut masak 72,94-75,66\% untuk semua perlakuan baik otot LD dan BF. Tinggi rendahnya susut masak mengambarkan jumlah nutrisi yang terlepas pada saat pemasakan. Daging dengan susut masak yang lebih rendah mempunyai kualitas yang relatif lebih baik daripada daging dengan susut masak yang lebih besar. Nilai susut masak ini masih dalam kondisi normal dari nilai susut masak pada umumnya yang bervariasi dengan kisaran 1,5-54,5\% (Soeparno, 2011).

\section{Keempukan daging}

Keempukan merupakan salah satu faktor kualitas daging yang dapat mempengaruhi konsumen. Nilai keempukan dibagi dalam empat kategori yaitu empuk (skala 0-3), cukup (skala 36), alot (skala 6-11), dan diatas 11 merupakan daging yang tidak layak dikonsumsi (Pearson, 1963). Keempukan daging menunjukkan tidak berbeda nyata $(\mathrm{P}>0,05)$ terhadap perlakuan level pakan konsentrat. Nilai rataan keempukan daging kambing Kacang yang mendapat perlakuan pemberian level konsentrat $0,5 \%$, $0,75 \%$, dan $1 \%$ dapat dilihat pada Tabel 3 . Nilai keempukan daging kambing Kacang penelitian dikategorikan empuk yaitu antara 0,53-0,92 $\mathrm{kg} / \mathrm{cm}^{2}$. Nilai keempukan daging otot $L$. dorsi $\left(0,62-0,92 \mathrm{~kg} / \mathrm{cm}^{2}\right)$, sedangkan ototl B. femoris $\left(0,53-0,58 \mathrm{~kg} / \mathrm{cm}^{2}\right)$. Daging yang empuk dalam penelitian ini disebabkan karena umur potong ternak masih muda ( $>1$ Tahun) . Lay (1996) melaporkan bahwa semakin tua umur ternak akan semakin alot dagingnya karena ukuran serat otot dan tekstur yang semakin kasar serta cenderung semakin tinggi kandungan jaringan ikatnya.

Keempukan daging memiliki hubungan dengan $\mathrm{pH}$ dan daya mengikat air daging. Daging dengan nilai derajat keasaman atau $\mathrm{pH}$ dan daya mengikat air tinggi mempunyai nilai keempukan daging yang lebih tinggi daripada daging dengan $\mathrm{pH}$ dan daya mengikat air yang rendah (Sudarman et al., 2008).

\section{Derajat keasaman atau pH}

Nilai $\mathrm{pH}$ daging menunjukkan tidak berpengaruh nyata $(\mathrm{P}>0,05)$ terhadap perlakuan level pakan konsentrat. Nilai $\mathrm{pH}$ pada penelitian ini jika dihubungkan dengan penanganan saat dan setelah dilakukan pemotongan maka nilai $\mathrm{pH}$ tersebut masih berada dalam kisaran normal, sesuai SNI 01:3948 (BSN, 1995) derajat keasaman yang normal dari daging kambing adalah pada kisaran 5,3-5,8. Faktor yang mempengaruhi perubahan $\mathrm{pH}$ adalah konsumsi pakan, stress saat pemotongan, spesies, individu ternak, macam otot (Soeparno, 2011). Nilai pH akhir daging yang baik antara 5,3-5,7 yang dicapai lebih dari 24 jam setelah proses kematian. Soeparno (2011) melaporkan pH normal daging adalah antara 5,4-5,8. Hasil penelitian ini menjukkan bahwa kambing Kacang saat dipotong tidak mengalami cekaman atau stress yang signifikan karena nilai $\mathrm{pH}$ yang dihasilkan setelah pemotongan tidak 
menujukkan variasi yang tinggi. Nilai $\mathrm{pH}$ daging merupakan faktor kualitas yang akan berpengaruh terhadap daya mengikat air, keempukan dan susut masak. Kenaikan $\mathrm{pH}$ daging akan meningkatkan daya mengikat air dan menurunkan susut masak daging kambing Kacang. Sifat-sifat fisik daging dapat ditemukan dengan mengukur $\mathrm{pH}$, daya ikat air, susut masak, keempukan, warna serta flavour dan aroma (Lawrie, 2003).

\section{Daya mengikat air (DMA) daging}

Nilai rataan persentase daya mengikat air pada daging kambing Kacang yang mendapat perlakuan pemberian pakan konsentrat dengan level $0,5 \%, 0,75 \%$, dan $1 \%$ dapat dilihat pada Tabel 3. Daya mengikat air menunjukkan tidak berpengaruh nyata $(\mathrm{P}>0,05)$ terhadap perlakuan pakan konsentrat. Daya mengikat air (DMA) yang diperoleh dalam penelitian berada dalam kisaran 33,94-39,05\%. Hal tersebut berhubungan dengan nilai $\mathrm{pH}$ daging kambing Kacang yang juga tidak berbeda nyata. Daya mengikat air (DMA) daging akan berbeda apabila terdapat perbedaan $\mathrm{pH}$ daging tersebut (Lawrie, 2003). Selain itu, diduga karena umur dan posisi sampel otot yang digunakan dalam pengujian. Rihi (1997) menyatakan bahwa ternak muda akan memiliki nilai daya ikat air yang lebih tinggi dari ternak dewasa karena semakin tinggi umur ternak, kadar air tubuh menurun. Daya mengikat air yang rendah akan menyebabkan daing mengeluarkan air. Daging menjadi lembek, basah, dan memperlihatkan warna pucat.

\section{KESIMPULAN}

Pemberian konsentrat dengan level 0,5\%; $0,75 \%$; dan $1 \%$ BB menghasilkan kualitas fisik daging yang sama pada otot Longissimus dorsi dan Biceps femoris kambing Kacang.

\section{DAFTAR PUSTAKA}

BSN [Badan Stadarisasi Nasional]. 1995. Daging Kambing/Domba. SNI 01:3948. Badan Stadarisasi Nasional. Jakarta.

Isyqzamiyah, S., R. Aka, dan A. Murlina Tasse. 2017. Mutu daging sapi bali yang dimarinasi dalam jus buah pinang. JITRO 4(2):19-24.

Lawrie, R.A. 2003. Ilmu Daging. Edisi Kelima. Universitas Indonesia-Press. Jakarta.
Lay, W. A. 1996. Produksi Karkas dan Kualitas Fisik Daging Spayed Heifer Brahman Cross dengan Pemberian Ransum Feedlot yang Mengandung Bungkil Biji Kapok (Ceiba pentandra). Thesis, Program Pasca Sarjana Universitas Gadjah Mada.

Mirdhayati, I., J. Hermanianto, C.H. Wijaya, \& D. Sajuthi. 2014. Carcass profile and chemical characteristic of male kacang goat (Capra aegragus hircus). JITV 19 (1):26-34..

Onwuka, C.F.I. 1999. Molasses block as supplementary feed resource for ruminants. Arch. Zootec. 48:89-94.

Pearson, A. M. \& R. B. Young. 1989. Muscle and Meat Biochemistry. Academic Press, Inc. London.

Rihi, J.L. 1997. Kinerja Karkas dan Kualitas Daging Domba Kacang Berdasarkan Jenis Kelamin dan Bobot Potong. Thesis. Universitas Gadjah Mada, Yogyakarta.

Sudarman, A., M. Muttakin, dan H. Nuraini. 2008. Penambahan sabun-kalsium dari minyak ikan lemuru dalam ransum: 2 . Pengaruhnya terhadap sifat kimia dan fisik daging domba. JITV 3(2):133-139.

Soeparno. 2011. Ilmu dan Teknologi Daging. Gadjah Mada University Press, Yogyakarta.

Steel, R. G. D. and J. H. Torrie. 1980. Principles and Procedures of Statitics. McGraw-Hill, New Work. 